\title{
PERAN ISLAMIC SOCIAL REPORTING TERHADAP NILAI PERUSAHAAN
}

\begin{abstract}
This study aimed to obtain empirical evidence about the influence of profitability and the disclosure of Islamic Social Reporting (ISR) on firm value on Islamic banking in Indonesia. The population of this research is all of Islamic Bank in Indonesia 2014 - 2016. The sample of this research is Islamic Bank in Indonesia by using purposive sampling method. There are eleven banks and obtained 44 observations. Classic assumption test performed for data analysis and regression analysis to test the hypothesis. The results of this study indicate that Profitability significantly influence the level of Social Reporting Islam and corporate values, Islamic Social Reporting does not affect the value of the company While profitability has a significant effect on corporate value, while the ISR has no significant effect on the level of corporate value.
\end{abstract}

Keywords: Islamic Social Reporting, Firm Value,, Profitability,

\section{PENDAHULUAN}

Pesatnya perkembangan bank syariah khususnya di Indonesia tentunya akan mendorong regulator untuk menetapkan peraturan-peraturan dan standar akuntansi bagi bank syariah. Dalam skala internasional terdapat Accounting and Auditing Organization for Islamic Financial Institutions (AAOIFI) yaitu organisasi internasional yang memiliki wewenang dalam penetapan standar akuntansi, pengauditan, tata kelola, dan etika syariah untuk institusi keuangan syariah di dunia. Selain itu pesatnya perkembangan bank syariah juga mendorong bank syariah untuk dapat melaporkan pengungkapan tanggung jawab sosialnya yang sesuai dengan prinsipprinsip syariah Islam.

Terkait dengan pengungkapan tanggung jawab sosial suatu entitas syariah, akhir-akhir ini marak diperbincangkan mengenai Islamic Social Reporting. Islamic Social Reporting adalah standar pelaporan kinerja sosial perusahaan berbasis syariah. Islamic Social Reporting merupakan kerangka khusus untuk pelaporan pertanggungjawaban sosial yang sesuai dengan prinsip Islam. Tujuan dari Islamic Social Reporting sendiri adalah sebagai bentuk akuntabilitas perusahaan kepada Allah SWT dan masyarakat dan juga meningkatkan transparansi kegiatan bisnis dengan menyajikan informasi yang relevan dengan memperhatikan kebutuhan spiritual investor muslim atau kepatuhan syariah dalam pengambilan keputusan.

Islamic Social Reporting terdiri atas item-item standarCSRyang ditetapkan AAOIFI (Accounting and Auditing Organization for Islamic Institutions) dan kemudian dikembangkan lagi oleh para peneliti mengenai itemitem CSR yang patut diungkapkan oleh suatu entitas Islam. Indeks ISR tersebut berisi 6 (enam) tema antara lain: investasi dan keuangan, produk dan jasa, karyawan, masyarakat, lingkungan, serta tata kelola perusahaan. 
Masing-masing tema memiliki indikator-indikator, yang seluruhnya berjumlah 43 indikator.

Studi mengenai pengungkapan tanggung jawab sosial yang dilakukan Haniffa (2002) menjelaskan bahwa ada keterbatasan pada kerangka pelaporan sosial yang dilakukan oleh lembaga konvensional. Keterbatasan tersebut mencakup aspek-aspek spiritual dan moral, sebab dalam prinsip syariah tidak hanya berfokus kepada aspek material saja seperti zakat, status kepatuhan syariah dan transaksi yang sudah terbebas dari unsur riba, serta aspek social seperti sodaqoh, waqof, qordul hasan, sampai dengan pengungkapan peribadahan di lingkungan perusahaan. Karenanya diperlukan sebuah kerangka pelaporan sosial yang berdasarkan prinsip syariah dalam mengembangkan Islamic Social Reporting untuk mencapai tujuan akuntabilitsas dan transparansi. Dengan tercapainya akuntabilitas dan transparansi laporan keuangan maka akan dapat memberikan dampak terhadap kenaikan nilai perusahaan dengan melalui harga pasar saham.

Beberapa penelitian yang telah dilakukan mengenai Islamic Social Reporting (ISR), antara lain Astuti (2014) yang meneliti tentang faktor-faktor yang mempengaruhi pengungkapan Islamic Social Reporting pada Bank Syariah di Indonesia. Hasil penelitian tersebut menunjukkan bahwa profitabilitas tidak berpengaruh terhadap pengungkapan Islamic Social Reporting.

Aldehita Purnasanti Maulida et.al (2014), melakukan penelitian pada perusahaan yang terdaftar pada Jakarta Islamic Index (JII), bahwa profitabilitas dan variabel kinerja lingkungan secara partial berpengaruh terhadap pengungkapan Islamic Social Reporting (ISR) perusahaan syariah di Jakarta Islamic Index (JII). Irman Firmansyah dan Eko Hariyanto (2014), melakukan penelitian pada perbankan syariah di Indonesia, hasil penelitian menunjukkan bahwa ukuran perusahaan dan dewan komisaris berpengaruh positif terhadap pengungkapan sosial perbankan syariah, sementara profitabilitas dan likuiditas tidak berpengaruh terhadap pengungkapan sosial perbankan syariah. Penelitian Rita Rosiana et.al. (2015) melakukan penelitian pada bank umum syariah di Indonesia. Hasil penelitian menunjukkan bahwa ukuran perusahaan memiliki pengaruh signifikan terhadap pengungkapan pelaporan sosial Islam, sedangkan profitabilitas dan leverage tidak berpengaruh terhadap Islamic Social Reporting. Hasil penelitian yang dilakukan oleh Rizqia dkk, (2013) menunjukkan bahwa profitabilitas berpengaruh positif terhadap nilai perusahaan. Berdasarkan penelitianpenelitian tersebut terdapat beberapa hasil yang tidak konsisten sehingga perlu dilakukan pengujian lebih lanjut untuk mengetahui konsistensi temuan jika diterapkan pada kondisi lingkungan yang berbeda.

Adapun rumusan masalah dalam penelitian ini adalah: Apakah Profitabilitas dan Islamic Social Reporting berpengaruh terhadap Nilai Perusahaan. Penelitian ini memiliki tujuan yaitu untuk menguji pengaruh Profitabilitas dan Islamic Social Reporting terhadap Nilai Perusahaan.

\section{KAJIAN PUSTAKA DAN PENGEMBANGAN HIPOTESIS}

Legitimasi organisasi dapat dilihat sebagai sesuatu yang diberikan masyarakat kepada perusahaan dan sesuatu yang diinginkan atau dicari perusahaan dari masyarakat (Chariri dan Ghozali, 2007). Teori legitimasi memfokuskan untuk menganjurkan perusahaan agar meyakinkan bahwa aktivitas dan kinerja yang dilakukan perusahaan dapat diterima oleh masyarakat.

Teori stakeholder adalah teori yang umumnya berkaitan dengan cara-cara yang digunakan perusahaan 
untuk mengelola stakeholdernya (Gray et al. 1997 dalam Chariri dan Ghozali, 2007). Salah satu strategi yang digunakan perusahaan untuk menjaga hubungan dengan para stakeholder-nya adalah dengan melakukan pengungkapakan informasi sosial dan lingkungan.

Indeks ISR berisi kompilasi item-item standar CSR yang ditetapkan oleh AAOIFI (Accounting and Auditing Organization for Islamic Financial Institutions) yang kemudian dikembangkan oleh para peneliti mengenai item-item CSR yang seharusnya di ungkapkan oleh suatu entitas Islam (Haryanti,2012). Ada enam tema pengungkapan dalam indeks ISR yaitu, investasi dan keuangan, produk dan jasa, tenaga kerja, sosial, lingkungan dan tata kelola perusahaan.

Terdapat banyak faktor yang mempengaruhi tingkat pengungkapan ISR. Pada penelitian ini dipilih profitabilitas, ukuran perusahaan, kinerja lingkungan dan leverage yang diprediksi dapat mempengaruhi pengungkaan ISR terkait sejauh mana informasi dari item-item ISR diungkapkan dalam laporan tahunan perusahaan.

\section{Pengaruh Profitabilitas Terhadap Pengungkapan Islamic Social Reporting (ISR)}

Profitabilitas merupakan rasio kemampuan perusahaan memperoleh keuntungan dan untuk melihat keefektifan manajemen suatu perusahaan dalam mengungkapkan tanggung jawab sosialnya (Maulida et al., 2014). Profitabilitas merupakan faktor yang membuat manajemen menjadi bebas dan fleksibel untuk mengungkapkan pertanggung jawaban sosial. Perusahaan yang berada pada posisi menguntungkan akan cenderung melakukan pengungkapan informasi yang lebih luas dalam laporan tahunannya. Profitabilitas digunakan untuk menilai kemampuan perusahaan dalam mencari keuntungan dan untuk melihat kefekektivan manajemen suatu perusahaan dalam mengungkapkan tanggung jawab sosialnya. Semakin tinggi profitabilitas berarti semakin tinggi kemampuan perusahaan dalam menghasilkan laba sehingga akan semakin luas pengungkapan yang dilakukan perusahaan.

Hasil penelitian yang dilakukan Maulida et.al (2014) menunjukkan bahwa profitabilitas berpengaruh terhadap luas pengungkapan ISR. Berdasarkan uraian tersebut dirumuskan hipotesis sebagai berikut:

\section{H1: Profitabilitas berpengaruh positif terhadap pengungkapan Islamic Social Reporting(ISR)}

\section{Pengaruh Profitabilitas terhadap Nilai Perusahaan}

Komitmen yang tinggi untuk memperbaiki kinerja didalam peusahaan hal ini akan membuat pasar berani untuk membeli sahamnya. Dengan alasan mereka akan mendapatkan keuntungan lebih dari perusahaan tersebut. Banyak penelitian tentang profitabilitas pada perusahaan terhadap nilai perusahaan. Salah satunyan dari hasil penelitian Rinati (2009) yang menjelaskan pengaruh ROA (Return On asset) terhadap harga saham. Jogianto dan Chendrawati (1999) dalam Dwijayanti, dkk (2012) menyatakan ROA (Return On Asset) sangat berpengaruh terhadap return saham dibandingkan EVA. ROA berpengaruh positif terhadap suatu nilai perusahaan yang diproksikan dengan return saham dalam satu periode ke depannya, Ulupui (2007). Nilai perusahaan tidak mempengaruhi OPM dan NPM dengan mengunakan PBV. Suranta dan Pratana 2004 dan Kaaro (2002) dalam Yuniasih dan Wirakusuma (2007) penelitian yang dilakukan Suranta dan Pratana) 
menekankan suatu profitabilitas

Berdasarkan penjelasan di atas, sehingga hipotesis yang dapat disusun adalah:

H2 : Pr of itabilitas perusahaan berpengaruh positif terhadap suatu nilai perusahaan

Pengaruh ISR perusahaan terhadap suatu Nilai Perusahaan

Nilai perusahaan itu sendiri dapat didevinisikan sebagai persepsi suatu investor yang ditujukan oleh perusahaan terbuka, yang sering sekali diperkaitkan dengan harga saham perusahaan (Sujoko dan Soebiantoro, 2007). Perusahaan yang dikatakan mempunyai nilai perusahaan yang tinggi akan tercermin dari nominal harga saham. Karena kepercayaan suatu pasar akan dilihat dari nilai perusahaannya, tidak hanya dilihat dari kinerja perusahaannya tetapi juga prospek suatu jangka panjang suatu perusahaan. (Hardiyanti, 2012).

Kepentingan Shareholder maupun stakeholder akan terpenuhi dengan cara mempertingkatkan laba maka suatu perusahaan harus memiliki nilai perusahaan yang baik. Suatu perusahaan akan mengeluarkan sejumlah pengeluaran yang pada akhirnya akan menjadi beban dan akan mengurangi pendapatan perusahaan akibatnya profit pada perusahaan tersebut akan turun itu semua akan terjadi saat perusahaan tersebut melakukan ISR atau Islamic Social Responsibility. Tapi, apa bila suatu perusahaan tersebut melakukan ISR atau Islamic Social Responsibility maka perusahaan tersebut akan mendapatkan nilai perusahaan yang baik. Berdampaknya loyalitas konsumen menjadi semakin tinggi.

Berdasarkan penjelasan di atas, sehingga hipotesis yang dapat disusun adalah:

\section{H3 : ISR berpengaruh positif terhadap nilai perusahaan.}

\section{METODE PENELITIAN}

Populasi yang digunakan dalam penelitian ini adalah seluruh bank umum syariah yang ada di Indonesia. Adapun teknik pengambilan sampel menggunakan metode purposive sampling, yaitu bank umum syariah yang menerbitkan laporan tahunan 2014-2016. Jenis data yang digunakan merupakan data sekunder yang berasal dari laporan keuangan tahunan, dimana data tersebut dapat diperoleh pada situs masing-masing bank umum syariah.

Teknik pengumpulan data dalam penelitian ini dilakukan dengan metode studi dokumentasi yaitu pengumpulan data melalui dokumen, dalam hal ini data laporan tahunan diperoleh melalui situs masingmasing bank umum syariah dan studi pustaka yaitu pengumpulan data sebagai landasan teori serta penelitian terdahulu melalui buku- buku, penelitian terdahulu, serta sumber tertulis lainnya yang berhubungan dengan informasi yang dibutuhkan. Metode analisis data dalam penelitian ini meliputi statistik deskriptif, uji normalitas data, uji multikolinearitas, uji autokorelasi dan uji heterokedastisitas. Dan pengujian hipotesis menggunakan analisis regresi linier berganda.

\section{Definisi Operasional Variabel dan Pengukuran}

Pengungkapan Islamic Social Reporting

Dalam penelitian ini indeks Islamic Social Reporting digunakan untuk mengetahui tingkat pengungkapan 
Islamic Social Reporting di dalam laporan tahunan bank umum syariah dengan menggunakan indeks penelitian Haniffa (2002) dan dimodifikasi dengan item-item pengungkapan pada penelitian Othman et al. (2009). Masing-masing item pengungkapan memiliki skor 1 atau 0. Skor 1 akan diberikan apabila item Islamic Social Reporting terdapat dalam data perusahaan dan skor 0 akan diberikan apabila item Islamic Social Reporting tidak ditemukan dalam data perusahaan.

Cara yang dilakukan untuk melakukan penilaian perbandingan antara pengungkapan Islamic Social Reporting Disclosure (ISRD) adalah dengan melakukan perbandingan antara pengungkapan Islamic Social Reporting yang sudah dilakukan oleh perusahaan dengan jumlah maksimum pengungkapan Islamic Social Reporting harus diungkapkan oleh perusahaan. Dengan demikian, formula ISRD adalah sebagai berikut: Jumlah Skor disclosure yang dipenuhi

Disclosure level $\quad=$

Jumlah skor maksimum

\section{Profitabilitas}

Profitabilitas adalah kemampuan suatu perusahaan untuk memperoleh keuntungan (profit). Profitabilitas dalam penelitian ini diukur dengan menggunakan ROA (Return On Asset). ROA adalah perbandingan antara laba bersih setelah pajak dengan total aset. Secara matematis ROA dapat diformulasikan sebagai berikut: (Sartono, 2008).

$$
\text { ROA = } \begin{gathered}
\text { Laba Bersih } \\
\text { Total Asset }
\end{gathered}
$$

\section{Nilai Perusahaan}

Nilai perusahaan dapat didefinisikan sebagai nilai pasar, seperti suatu penelitian yang pernah dilakukan Nurlela dan Islahuddin (2008). Dengan kata lain, nilai perusahaan merupakan harga yang sedia dibayar oleh investor seandainya perusahaan dijual Rasio penilaian sangat penting karena rasio tersebut berkaitan langsung dengan tujuan memaksimalkan nilai perusahaan dan kekayaan para pemegang saham. Rasio penilaian tersebut adalah market value ratio yang terdiri dari 3 macam rasio yaitu price earning ratio, price/cash flow ratio dan price to book value ratio.

Price earning ratio adalah rasio harga per lembar saham terhadap laba per lembar saham. Rasio ini menunjukkan berapa banyak jumlah rupiah yang harus dibayarkan oleh para investor untuk membayar setiap rupiah laba yang dilaporkan. Price/cash flow ratio adalah harga per lembar saham dengan dibagi oleh arus kas per lembar saham. Sedangkan Price to book value ratio adalah suatu rasio yang menunjukkan hubungan antara harga pasar saham perusahaan dengan nilai buku perusahaan (Weston \& Copeland, 1997).

Harga pasar per lembar saham

$\mathrm{PER}=$

Nilai buku per lembar saham 


\section{Analisis Regresi Linier Berganda}

Ghozali (2011) menyatakan bahwa dalam analisis regresi, selain mengukur kekuatan hubungan antara dua variabel atau lebih, juga menunjukkan arah hubungan (pengaruh) antara variabel independen dengan variabel dependen. Penelitian ini akan menguji factor-faktor yang mempengaruhi pengungkapan Islamic Social Report (ISR) pada perbankan syariah di Indonesia.

$$
\begin{gathered}
\text { ISR }=\alpha+\beta 1, \text { Proft }+\varepsilon \\
N P=\alpha+\beta 1, \text { Proft }+\beta 2 . \text { ISR }+\varepsilon
\end{gathered}
$$

Dimana:

ISR : :Tingkat Pengungkapan ISR

a : Konstanta

$\beta 1-\beta 3 \quad$ : Koefisien Regresi

Proft : Profitabilitas

NP : Nilai perusahaan

$\varepsilon \quad$ : Error Term

\section{HASIL DAN PEMBAHASAN}

\section{Hasil Uji Normalitas}

Uji normalitas data bertujuan untuk menguji apakah variabel yang diuji memiliki distribusi normal atau tidak. Model regresi yang baik adalah memiliki distribusi normal atau mendekati normal. Asumsi ini diuji dengan menggunakan Uji Kolmogorove-Smirnov. Berikut adalah hasil Uji Kolmogorov-Smirnov dalam penelitian ini:

\section{Hasil Uji Multikolinearitas}

Uji multikolinearitas digunakan untuk mengetahui ada atau tidaknya hubungan linear antar variabel independen dalam model regresi (Sujarweni, 2014). Model dinyatakan terbebas dari gangguan multikolinearitas jika mempunyai nilai VIF dibawah 10 atau tolerance diatas 0,1 . Hasil pengujian multikolinearitas sebagai berikut:

\section{Hasil Uji Heteroskedastisitas}

Uji Heteroskedastisitas bertujuan menguji apakah dalam model regresi terjadi ketidaksamaan variance dari residual satu pengamatan ke pengamatan yang lain. Hasil uji sebagai berikut:

Berdasarkan tabel diatas, dapat dilihat bahwa nilai signifikansi > 0,05. Hal ini dapat dinyatakan bahwa tidak terjadi heteroskedastisitas dalam model penelitian ini.

Jurnal Akuntansi Indonesia

62 


\section{Analisis Regresi Linier Berganda Pertama}

Berdasarkan hasil perhitungan dengan menggunakan SPSS diperoleh hasil pada tabel 4

\section{Uji Hipotesis}

\section{Pengaruh Profitabilitas Terhadap Pengungkapan ISR}

Pengujian model regresi yang dilakukan dalam penelitian ini menunjukkan bahwa variabel Profitabilitas memiliki nilai thitung sebesar 0,196 dan signifikansi 0,246>0,05 Jadi dapat disimpulkan bahwa H1 dalam penelitian ini ditolak).

Hasil pengujian pada variable Profitabilitas diproksikan dengan Return On Asset (ROA) menunjukkan profitabilitas tidak memiliki pengaruh signifikan terhadap pengungkapan Islamic Social Reporting (ISR) pada perbankan syariah di Indonesia. Kondisi ini terjadi karena profitabilitas menunjukkan bahwa perusahaan yang mempunyai profitabilitas naik belum tentu lebih banyak melakukan aktivitas sosial karena perusahaan lebih berorientasi pada laba semata. Ketika perusahaan memiliki tingkat laba yang tinggi, perusahaan (manajemen) menganggap tidak perlu melaporkan hal-hal yang dapat mengganggu informasi mengenai keberhasilan pengelolaan keuangan perusahaan.

Sebaliknya, pada saat tingkat profitabilitas rendah, mereka berharap para pengguna laporan akan membaca "Good news" kinerja perusahaan. "Good news" ini dapat berupa aktivitas-aktivitas sosial lingkungan yang dilakukan oleh perusahaan. Berdasarkan pendapat Haniffa (2002) bahwa dalam pandangan Islam, perusahaan yang memiliki niat untuk melakukan pengungkapan tidak akan mempertimbangkan apakah perusahaan tersebut untung atau rugi. Artinya, besar kecil suatu pengungkapan tidak ditentukan oleh besar kecilnya profitabilitas, dan tetap mengungkapkan informasi Islamic Social Reporting terlepas dari tinggi atau rendahnya profit yang mereka miliki.

Hal ini dikarenakan perusahaan memandang pengungkapan Islamic Social Reporting sebagai suatu kebutuhan. Perusahaan menyadari bahwa pengungkapan Islamic Social Reporting sangat penting sebagai wujud transparansi perusahaan untuk dapat menambah kepercayaan serta nilai perusahaan dimata para pengguna laporan.

Sehingga hasil penelitian ini konsisten dengan penelitian yang dilakukan Firmansyah dan Hariyanto (2014) menunjukkan bahwa profitabilitas tidak mempengaruhi tingkat pengungkapan ISR.

\section{Analisis Regresi Linier ke Dua}

Berdasarkan hasil perhitungan dengan menggunakan SPSS diperoleh hasil pada tabel 4

\section{Pengaruh Profitabilitas terhadap Nilai Perusahaan}

Berdasarkan perhitungan didapat bahwa Profitabilitas yang diukur menggunakan ROA berpengaruh terhadap nilai perusahaan dengan mempunyai nilai,t hitung sebesar 2,802 dengan signifikansi sebesar 0,036 (lebih kecil dari 0,05). Hasil pengujian ini dapat menunjukan bahwa profitabilitas berpengaruh signifikan terhadap nilai perusahaan.. ROA adalah nilai yang mencerminkan pengembalian perusahaan dari 
seluruh aktiva (pendanaan)yang diberikan pada perusahaan. Rasio ini merupakan perbandingan antara laba bersih setelah pajak dengan total aktiva yang dimiliki perusahaan. Hasil ini mendukung teori yang dikemukakan oleh Modigliani dan Miller yang menyatakan bahwa nilai perusahaan ditentukan oleh earning power dari aset perusahaan. Hasil yang positif menunjukkan bahwa semakin kecil earning power semakin efisien perputaran asset atau semakin besarl profit margin yang diperoleh oleh perusahaan. Hal ini berdampak pada kenaikan nilai saham. Nilai signifikan ini diperoleh karena semakin tinggi rasio ini maka semakin baik produktivitas asset dalam memperoleh keuntungan bersih. Hal ini selanjutnya akan meningkatkan daya tarik perusahaan kepada investor, sehingga akan mempengaruhi nilai perusahaan.

Hasil ini mendukung penelitian yang sudah dilakukan oleh Hermawati (2011) yang menyatakan bahwa profitabilitas yang diproksikan melalui ROA berpengaruh signifikan terhadap nilai perusahaan.

Pengaruh ISR terhadap Nilai Perusahaan

Berdasarkan perhitungan didapat bahwa Islamic Social Reporting tidak berpengaruh terhadap nilai perusahaan dengan mempunyai nilai,t hitung sebesar 1,126 dengan signifikansi sebesar 0,289 (lebih besar dari 0,05). Hasil pengujian ini dapat menunjukan bahwa Islamic Social Reporting tidak berpengaruh signifikan terhadap nilai perusahaan.

ISR merupakan salah satu strategi jangka panjang dalam usaha untuk keberlangsungan perusahaan dan melaporkan laporan keuangan untuk mencapai akuntabilitas sehingga dapat mempengaruhi terhadap nilai perusahaan melalui harga sahamnya. Tetapi dalam penelitian ini bahwa ISR tidak berpengaruh terhadap nilai perusahaan. Umumnya investor di Indonesia lebih cenderung membeli saham untuk memperoleh capital gain, yang cenderung membeli dan menjual saham secara harian (daily trader), tanpa memperhatikan keberlangsungan perusahaan dalam jangka panjang. Investor lebih memilih saham dengan melihat pada market economy dan berita-berita yang muncul.

\section{SIMPULAN}

Adapun simpulan dalam penelitian ini adalah :

Profitabilitas berpengaruh terhadap pengungkapan ISR karena profitabilitas menunjukkan bahwa perusahaan yang mempunyai profitabilitas naik belum tentu lebih banyak melakukan aktivitas sosial karena perusahaan lebih berorientasi pada laba semata

Profitabilitas berpengaruh terhadap nilai perusahaan, semakin baik labanya maka akan meningkat nilai pendowonya.

Islamic Social Reporting tidak berpengaruh terhadap nilai perusahaan.karena para pembeli/ inverstor cenderung membeli saham untuk mendapatkan capital gain.

\section{SARAN}

Adapun saran yang dapat diberikan adalah:

Bagi bank syariah dapat mengungkapkan Islamic Social reporting secara lebih luas dan lebih baik lagi

Bagi regulator agar dapat menciptakan system dan peraturan baku dalam penentuan pengungkapan ISR untuk perusahaan berbasis syariah. 


\section{DAFTAR PUSTAKA}

An, Yi; Davey, Howard; and Eggleton, lan R. C. 2011. The Effects of Industry Type, Company Size and Performance on Chinese Companies' IC Disclosure: A Research Note, Australasian Accounting, Business and Finance Journal, 5(3), 107-116. Available at:http://ro.uow.edu.au/aabfj/vol5/iss3/8

Aldehita Purnasanti Maulida et.al. 2014. Analisis Faktor-faktor yang Mempengaruhi Pengungkapan Islamic Social Reporting (ISR). Jurnal SNA 17 Mataram, Lombok Universitas Mataram. 24-27 Sept 2014.

Amirul Khoirudin. 2013. Corporate Governance Dan Pengungkapan Islamic Social Reporting Pada Perbankan Syariah di Indonesia. Accounting Analysis Journal, Volume 2 Nomor 2. Semarang: Universitas Negeri Semarang.

Chariri A dan Ghozali I, 2007. Teori Akuntansi. Semarang : BP Universitas Diponegoro

Faisal S. Alanezi and Mishari M. Alfaraih, et.al. 2012. Dual/Joint Auditors And The Level Of Compliance With International Financia I Reporting Standards (IFRS-Required Disclosure) The Case Of Financial Institutions In Kuwait. Journal of Economic and Administrative Sciences Vol. 28 No. 2, pp. 109-129.

Grais, W., \& Pellegrini, M. (2006). Corporate Governance and Stakeholders' Financial Interests in Institutions Offering Islamic Financial Services. World Bank Policy Research Working Paper 4053.

Ghozali, I. 2011. Aplikasi Analisis Multivariate Dengan Program SPSS. Semarang: BP Universitas Diponegoro Haniffa, R.M. and Hudaib, M.A. (2002), "A Conceptual Framework for Islamic Accounting:The Shari冈a Paradigm", paper presented at the Accounting, Commerce \& Finance: The Islamic Perspective International Conference IV, New Zealand

Haryanti, C.S (2012). "Faktor-Faktor yang MempengaruhiPemanfaatan Personal

Komputer". Jurnal Ilmiah UNTAG Semarang.

Irman Firmansyah dan Eko Hariyanto. 2014. Analisis Pengungkapan Kinerja Sosial (Social Disclosure) Pebankan Syariah Di Indonesia Dan Malaysia Dalam Perspektif Islamic Social Reporting. Buletin Ekonomi Vol.12, No. 1,April 2014 hal 1-124

Maali, B., Casson, P., \& Napier, C. 2006. Social Reporting by Islamic Banks. Accounting Foundation, The University of Sydney. 266-289.

Maulida et.al. 2014. Analisis Faktor-faktor yang Mempengaruhi Pengungkapan Islamic Social Reporting (ISR). JurnaISNA 17 Mataram, Lombok Universitas Mataram. 24-27 Sept 2014.

Murtanto and Elvina. The Effect Of Firm Characteristics To Voluntary Disclosure In Annual Report Of The Companies Listed In Jakarta Stock Exchange. Paper Presented At International Conference On Corporate Governance And Reporting, 25-26th. May, Malaysia. 2004.

Ningrum et.al. 2013. Pengaruh Kinerja Keuangan, Kepemilikan Institusional Dan Ukuran Dewan Pengawas Syariah Terhadap Pengungkapan ISR. Accounting Analysis Journal 2 (4) (2013)

Othman, R., Thani, A. M., \& Ghani, E. K. 2014. Determinants of Islamic Social Reporting Among Top ShariaApproved Companies in Bursa Malaysia. Research Journal of International Studies. 
Rahman, Azhar Abdul \& Abdullah Awadh Bukair. 2013. The Influence of the Shariah Supervision Board on Corporate Social Responsibility Disclosure by Islamic Banks of Gulf Co-Operation Council Countries. Asian Journal of Business and Accounting 6 (2).

Rizqia, Dwita Ayu. Aisjah, Siti dan Sumiati. 2013. Effect of Managerial Ownership, Financial Leverage, Profitability, Firm Size, and Investment Opportunity on Dividend Policy and Firm Value.Research Journal of Finance and Accounting. 4 (11), h: 120-130.

Rosiana et.al. 2015. Pengaruh Ukuran Perusahaan, Profitabilitas, Leverage, dan Islamic Governance Score Terhadap Pengungkapan Islamic Social Reporting (Studi Empiris pada Bank Umum Syariah di Indonesia Tahun 2010-2012). Jurnal Bisnis dan Manajemen, Vol. 5, No. 1, April 2015.

Siregar, Sylvia Veronica, and Sidharta Utama.(2008) "Type of earnings management and the effect of ownership structure, firm size, and corporate-governance practices: Evidence from Indonesia. The International Journal of Accounting 43.1: 1-27

Siregar, S., \& Utama, S. (2005). Pengaruh Struktur Kepemilikan, Ukuran Perusahaan, dan Praktek Corporate Governance terhadap Pengelolaan Laba (Earning Management). Simposium Nasional Akuntansi VII Solo, 15-16 September 2005, 475-490.

Tilling, M. V. 2004. Refinements to Legitimacy Theory in Social and Environmental Accounting. Commerce Research Paper Series no. 04-6.

Widiawati, S., \& Raharja, S. (2012). Analisis Faktor-Faktor yang Mempengaruhi Islamic Social Reporting Indeks Perusahaan-Perusahaan yang terdapat pada Daftar Efek Syariah Tahun 2009-2011. Dipponegoro Journal of Accounting, Volume 1, Nomor 2.

Winanda, Arsita Putri. 2009. "Analisis Pengaruh Penerapan Good Corporate Governance dan Struktur Kepemilikan terhadap Kinerja Perusahaan. Journal Simposium Akuntansi. 
Tabel 1

Uji Normalitas

\begin{tabular}{|l|c|c|}
\hline & $\begin{array}{c}\text { Kolmogorov- } \\
\text { SmirnovZ }\end{array}$ & $\begin{array}{c}\text { Asymp. Sig. } \\
\text { (2-tailed) }\end{array}$ \\
\hline Profitabilitas Institusional & 1,438 & 0,612 \\
\hline Islamic social reporting & 0,816 & 0,948 \\
\hline
\end{tabular}

Sumber:Pengolahan data SPSS,2017

Tabel 2

Uji Multikolinearitas

\begin{tabular}{|l|c|l|l|}
\hline \multirow{2}{*}{ Model } & \multicolumn{2}{|c|}{$\begin{array}{c}\text { Collinearity } \\
\text { Statistics }\end{array}$} & \multirow{2}{*}{ Keterangan } \\
\hline Profitabilitas & Tolerance & VIF & \\
\hline Islamic social reporting & .452 & 1.301 & $\begin{array}{c}\text { Tidak terjadi } \\
\text { Multikolinearitas }\end{array}$ \\
\hline
\end{tabular}

Sumber:Pengolahan data SPSS,2017

Table 3

Uji heterokedastisitas

\begin{tabular}{|l|l|l|l|}
\hline Model & T & Sig. & Keterangan \\
\hline Profitabilitas & .375 & .679 & Tidak terjadi heterokedastisitas \\
\hline Islamic social reporting & .435 & .662 & Tidak terjadi heterokedastisitas \\
\hline
\end{tabular}

Sumber:Pengolahan data SPSS,2017 
Tabel 4

\section{Uji Hipotesis}

\begin{tabular}{|l|l|l|l|l|}
\hline Hipotesis & \multicolumn{1}{|c|}{ B } & $\begin{array}{c}\text { T } \\
\text { hitung }\end{array}$ & $\begin{array}{c}\text { P } \\
\text { value }\end{array}$ & Kesimpulan \\
\hline Profitabilitas & 0,064 & 2,802 & 0,036 & Berpengaruh \\
\hline ISR & 0,046 & 1,126 & 0,289 & Tidak Berpengaruh \\
\hline
\end{tabular}

a. Dependent Variable: NP

\section{Tabel Hipotesis}

\begin{tabular}{|l|c|c|c|l|}
\hline Hipotesis & B & $\begin{array}{c}\text { T } \\
\text { hitung }\end{array}$ & $\begin{array}{c}\text { P } \\
\text { value }\end{array}$ & Kesimpulan \\
\hline Profitabilitas & 0,164 & 0,196 & 0,246 & Berpengaruh \\
\hline
\end{tabular}

a. Dependent Variable: ISR

Sumber:Pengolahan data SPSS,2017 